\title{
A Bridge over Troubled Waters (and Sands)? A Critical Sight on Spain's Role in Western Sahara Issue 40 Years Later
}

\author{
Javier A. GONZÁLEZ VEGA*
}

\begin{abstract}
Forty years after Spain's relinquishment of its legal responsibilities over the Western Sahara, its political attitude towards the territory -reflected in the official statement issued on 26 February 1976- confirmed the inability of the Spanish Government to abide the international norms on self-determination and its failed attempts to remain outside the situation. The Spanish role, conceived as a "constructive neutrality" has revealed a lot of contradictions, appeased through a patient but constant approach to the Moroccan thesis - expressed mainly in its passive role inside the Group of Friends of Western Sahara-, its muteness concerning the successive incidents related to the territory -specially concerning human rights situation-, its sympathies towards the Moroccan Autonomy Plan or its constant support to the measures related to the exploitation of Western Sahara natural resources due to the Spanish interests at stake. Far from having a presumed role of a bridge to contribute to settle the conflict, the "constructive neutrality" - conceived by Spanish authorities and promoted by Spanish think-tanks - appears really as a "benevolent neutrality" towards Morocco's position. A weak approach that proves the real limits of the Spanish foreign policy.
\end{abstract}

Keywords: Western Sahara - decolonization - self determination - Spain - foreign policy.

\section{(A) INTRODUCTION: ON THE SPAIN'S MUTISM BEFORE A TROUBLED ANNIVERSARY}

On the 4oth anniversary of Spain's relinquishment as administrator of the non-autonomous territory of Western Sahara, there had been considerable echoes of those regrettable and tragic events. Certainly, the strongest was by UN Secretary-General, Mr. Ban-Ki-Moon who paid a visit to the Tindouf Refugee camps for the first time last March, and declared that:

"The parties to the Western Sahara conflict have not made any real progress in the negotiations towards a just, lasting and mutually acceptable political solution. Through all this, we should be able to provide for the self-determination of the people of Western Sahara as the Security Council [has been] requesting since 2004 .

My first objective in visiting the region is to make my own assessment and contribution to the search for a settlement. I am grateful for my exchanges with Secretary-General Abdelaziz. I will spare no effort to help make progress. My discussions provided good elements in this regard.

My second objective was to visit the United Nations Mission for the Referendum in Western Sahara (MINURSO). I will visit the team site in Bir Lahlou, as well as personnel performing vital demining activities. I saw the remarkable and demanding work the Mission is doing in harsh conditions of the Hammada. I also expect to visit the headquarters of MINURSO in Laayoune, Western Sahara, soon.

Third, I wanted to bear witness to one of the forgotten humanitarian tragedies of our time. The Sahrawi refugee camps near Tindouf are some of the oldest in the world. It is heartbreaking to see

* Professor of Public International Law, Universidad de Oviedo (Spain). Email: javi.g.vega@gmail.com. This contribution has been funded by the Universidad de Oviedo and Banco de Santander Internship Program for Excellence Mobility (2016), through a stay as Gästwissenschaftler (Guest Researcher) in the Walter Schücking Völkerrechts Institut at the Christian Albrechts Universität zu Kiel between April, ist and June 15th 2016. I'm grateful to its director, Prof. Dr. Kerstin Odendahl for her invaluable support. 
these families separated for so long. The Sahrawis have endured a great deal of suffering in harsh conditions. I want to draw the world's attention to a population whose plight is often overlooked. This situation is unacceptable. Independently from the political process, the plight of the people must be addressed...

I have been heartened by the faith Sahrawi people put in the UN, its principles, and international law. Let us match this with determination to alleviate their plight and resolve this longstanding conflict for the better future of all Sahrawis."

One day later, the Secretary-General had a brief encounter with Algerian Foreign Minister, Mr. R. Lamamra. On this occasion, he said more emphatically, that:

"The world cannot forget the Sahrawi people. They must enjoy their human rights - their human dignity; even minimum human dignity I couldn't find from there- especially the right to selfdetermination within the framework of a mutually acceptable political solution.

Addressing the Western Sahara issue is a major purpose of my visit to this region. I am here with an urgent plea for more attention and action"

From the Moroccan side no special acts were held as usual, albeit in fact the date was the anniversary of the submission to the alaui Monarch by few members of the representative assembly of the territory - the Yemaa 3 - In fact, Morocco celebrated in November 2015 the recovering of the so called "Southern provinces", commemorating the fortieth anniversary of the "Green March" Moreover, the presence of the UN Secretary General was disturbing: Rabat did not agree to receive Mr. Ban Ki Moon during his trip to Maghreb countries and even on the occasion of subsequent press

I Remarks to the press following the meeting with Secretary-General of the Polisario Front, Rabouni (Algeria), 5 March 2016 (accessed Io June 2016). Surprisingly, no echoes of this statement were retained by our Foreign Affairs Ministry, notwithstanding the fact that Mr. Ban Ki Moon was received previously in Madrid by the Minister, Mr. M. García-Margallo Marfil - revealing that the trip was mainly related to Western Sahara Question- and the SG and his personnel travelled to Tindouf in two FAE (Spanish armed forces) planes. On the details of the interview, see FACM, Press Note no. O43, 2 March 2016 (accessed ro June 2016).

2 Remarks at Ministry of Foreign Affairs, Algiers, 6 March 2016 (accessed ro June 2016).

3 In fact, the General Assembly of Spanish Sahara (Yemaa), a tribal assembly created by Spain's administration (Decree no. I024/I967, II May; SOJ (BOE), no. I20, 20 May 1967) - previously denigrated by Morocco- was self-dissolved in December 1975, although some members loyal to Morocco held an "extraordinary" meeting in El Aaiún in 26 February 1976. The clearly Moroccan manipulation of this event was rejected by the UN Secretary General, Mr. K. Waldheim, who refused to send any representative. See F. Villar, La Transición exterior de España. Del aislamiento a la influencia (1976-1996), (Marcial Pons, Madrid, 2016), at 32. However, according to pro-Moroccan sources, in spite of the sabotage by Polisario Front and Algeria, the resigning Spanish Gobernador General was present there, legitimising the Moroccan -and Mauritanian, at this time- annexation of the territory. See J.Y. de Cara, "Souveraineté de Maroc sur le Sahara", in Ch. Saint-Prot, J-Y De Cara and Ch. Boutin (eds.), Sabara Marocain. Le dossier d'un conflit artificial (Les Éditions du Cerf, Paris, 2016), I31-156, at 153. Really, in spite of his presence, the Spanish "accidental” Governor, Lt. Col. R. Valdés, was duly instructed by the Spanish Government to make a statement addressed to the Western Sahara people -not to the Yemaa- and refused to sign the document approved by the assembly. See J.L. Rodríguez Jiménez, Agonía, Traición, Huída. El final del Sabara español, (Crítica, Barcelona, 2015), at 587.

4 According to Morocco is this event the real moment of re-integration of Western Sahara to its homeland, as a legitimate way to recover - supposedly, peacefully - unlawful occupied territories by foreign powers. Notwithstanding, although even Th.M. Franck spoke of "peaceful aggression" to qualify such illegal move ("The Stealing of the Sahara", 70 AJIL, (1976), 694-72I, at 714), is very doubtful the entirely peaceful character of this Moroccan "performance". See T. Barbulo, La bistoria probibida del Sábara español, (2nd ed., Destino, Barcelona, 20II). 
remarks made by the UNSG in Bir Lahlou', took advantage to create a scandal denouncing the supposed- biased position adopted by him 6 .

Then, in an unprecedented gesture, the Office of the UNSG was compelled to submit a communiqué where it is stated that:

"We have seen the statement of the Moroccan Ministry of Foreign Affairs. The status of the Western Sahara territory remains to be decided, as it is a non-self-governing territory. All UN member States, including Morocco, agree with this in yearly General Assembly resolutions adopted without a vote. The Security Council has called on the UN to facilitate negotiations aiming at a "mutually acceptable political solution, which will provide for the self-determination of the people of Western Sahara". Clearly, the issue at stake is the final status of the territory.

Last Saturday, the Secretary-General personally witnessed a desperate situation in a Western Sahara refugee camp resulting from decades of life without hope in the harshest conditions. He stressed that the Sahrawi refugees deserve a better future. He referred to "occupation" as related to the inability of Sahrawi refugees to return home under conditions that include satisfactory governance arrangements under which all Sahrawis can freely express their desires. The Secretary-General reiterated his call for genuine negotiations in good faith and without preconditions. The objective of restarting these negotiations in a more positive spirit is to provide hope to these people and enable them to return home.

Once again, the Secretary-General calls on the parties to seriously engage in negotiations."

In fact, the commemoration of the pending decolonization of the territory has been rhetorically fought by Morocco not only in the streets and international fora but also in the academic arena supported by some foreign jurists - through contributions trying to rewrite not only history, but even legal international acts related to the question?. Moreover, in the most recent campaign, the

5 The presence of Mr. Ki Moon in this place was due to the fact that there are the MINURSO facilities situated in the Sahrawi controlled side of the wall (berma) built by Morocco to safe Sahrawi territory under its control (On this question See J.A. González Vega, I., De la Rasilla, "Líneas en la arena...: El muro marroquí sobre el Sahara occidental a la luz de la legalidad internacional”, in R. Medina Martín, R.L Soriano Díaz (eds.), Activismos Políticos y Académicos en la causa sabaraui. Nuevas perspectivas críticas en Derecho, Política y Arte (Aconcagua Libros, Sevilla, 20I4), 73-Ioo). But, it must be remembered that there was here also that was proclaimed the Sahrawi Arab Democratic Republic on 27 February 1976. Then, the presence of UNSG was (inadvertently?) paying a symbolic tribute to the weakly recognized Sahrawi State.

6 A communiqué made public on 8 March 2016 by the Ministry of Foreign affairs through the MAP agency condemned, among other things, the - supposed- employ of the term "occupation" by the UNSG during his stay in Bir Lahlou (no records of this statement are available). Yet surprisingly, the Moroccan Foreign Affairs Ministry has erased its communiqué [See the blank page at MAP (Moroccan official news agency) website $<$ http://www.maroc.ma/fr/actualites/legouvernement-du-royaume-du-maroc-exprime-les-plus-vives-protestations-contre-les> (consulted ro June 2016)]. Although slightly biased, on this incident and its related developments, See F. Mohsen-Finan, "Morocco's indignation with Ban Kimoon: is the Western Sahara an 'occupied' territory?", ARI, no. 6I/20I6, 26 July 2016 (accessed 20 September 20I6).

7 Specially, see Sabara Marocain. Le dossier d'un conflit..., cit., with contributions of editors and B. Diallo, J.M. Gil Garre, K. Odendahl, A. El Ouali, Z. El Tibi and. H.L. Védie. The Moroccan position has been nurturred in the recent years by a lot of contributions insisting in the supposedly "biased" I975 opinion of ICJ -excluding the Islamic conception of International Law (See M. Khadduri, "Islamic International Law" in R Bernhardt (ed.), Encyclopedia of Public International Law, vol. 2, Elsevier, Amsterdam, 1995, I236-I242), in the so called erroneous doctrine of uti possidetis juris, claiming that "the artificial borders imposed by colonialism have helped to set the continent on a road to ruin, and the map of Africa should instead be redrawn in accordance with a legitimate exercise undertaken by entities defined along pre-colonial lines" ( $M$. Mutua, "Why Redraw the Map of Africa: A Moral and Legal Inquiry", I6 Michigan JIL, (1995), III8; cit. in K. Knop, "Statehood: territory, people, government", in J. Crawford, M. Koskenniemi (eds.), The Cambridge Companion to International Law (Cambridge UP, Cambridge, 20I2), 95-II6, at I04), and, last but not least in the well known discourse about failed States (See R. Jackson, Quasi-States: Sovereignty, International Relations and Third World (Cambridge UP, 
evident lack of legality and legitimacy of the persistent unlawful occupation of the territory - today, as always, not recognized by any State of the international community - is pervaded through elaborated arguments founded on security and geopolitical issues. In this sense, as has been pointed out:

"Morocco has even increased its reputation as security provider... This reputation enforces Moroccan interests in Western Sahara, while there are few countries in the region who want really a change in the status quo that has prevailed there for decades"

With regard the "geopolitical advantage factor", it was not a coincidence that King Mohamed VI's unwillingness to receive UN Secretary General, did not prevent him from travelling to Moscow where at an encounter with Prime Minister, Mr. V. Putin, they tried to reach an agreement over a common strategy to maintain the actual impasse on the issue?.

Apparently not such an intense reaction was registered on the Sahrawi side, although some commemorations were held at the end of February to commemorate the proclamation of the SADR. On the Spanish side, the interim Government refrained from taking part in any activity concerning Western Sahara in an astonishing muteness ${ }^{\mathrm{I}}$. Certainly, there were no communiqués remembering the abandonment of the territory, not even a remembrance of the 26 February 1976 Declaration, supposedly to be Spain's official position on the question, subsequent to Madrid Agreements until now ${ }^{\text {II }}$ Such mutism was even maintained when two months later the United Nations Security Council adopted the correspondent Resolution on MINURSO - the SC Res. 2285 (20I6), 29 April 2016- again notwithstanding the fact that as usual Spain's Foreign Affairs Ministry produces a mild communiqué on the issue and Spain is sitting at present on the SC as a permanent non-member in its last year of mandate ${ }^{\mathrm{r} 2}$.

Cambridge, 1990), at 202; cit., in J. Crawford, "Sovereignty as a Legal Value", in The Cambridge Companion to International..., at 127). In spite of these manoeuvers, the unique legal solution lies outside Morocco's arguments; conscious of it, really he pleads for an exception; however, as has been said, "the protracted nature of the conflict ... shows that such an exception only comes into question as an ultima ratio" (J. Fisch, The Right of Self-determination of Peoples: The Domestication of an Illusion, (transl. A. Mage), (Cambridge, Cambridge UP, 2015), at 222).

8 F. Ghilès, "El progreso de Marruecos es lento, frágil pero real", I25 Notes Internacionals CIDOB (July, 2015), at 3 (in Spanishaccessed 20 June 2016. Translation by the author).

9 Apparently, the move was unfruitful as the later abstention and statement of Russian Permanent Representative in the meeting 7684 of 29 April 2016 of the SC revealed (See below, 3). Anyway, is futile to insist on the willingness of Russian President, Mr. Putin, for Geopolitics instead of International Law, as the Ukraine Crisis showed. See R. Müllerson, "Geopolitics versus International Law: The Case of Ukraine", in G. Biaggini, O. Diggelmann, Ch. Kaufmann (eds.), Polis und Kosmopolis. Festscbrift für Daniel Tbürer (Dike-Nomos, Zurich-Baden Baden, 2015), 513-528.

ro Certainly, in sharp contrast with the 3oth Anniversary of the establishment of relations with Israel, surrounded of Declarations of Foreign Affairs Minister and social events. See FACM Press Note no. 029, I7 February 2016.

II See below, 3 .

I2 In fact, only short references to the negotiating procedure leading to the SC resolution 2285/20I6 are made in FACM Press Notes no. 055, I8 March 2016, no. 065, 8 April 2016, no. 070, I5 April 2016, and no. 083, 29 April 2016, and a brief summary of its content in Press Note no. 093, 6 May 2016 (texts available here, accessed is June 2016). However, in this case a communiqué would have been of interest, taking into account the controversies surrounding its adoption: the previous tensions between Morocco and SG, Mr. Ban Ki Moon - subsequent to its Declarations in Algiers concerning the issue-, the drastic reduction of MINURSO staff and the involvement of African Union in the negotiations. On these issues, see below, 3 . 
In fact, on this occasion, the silence was not understandable bearing in mind that the Resolution passed implies a significant reduction of MINURSO personnel due to the retaliatory measures adopted by Morocco in connection with the "Bir Lehlu incident" ${ }^{\text {"3 }}$. Yet, the only significant moves during these months were reflected in a succinct press note submitted after the encounter of SG Personal Representative to Western Sahara, Mr. Ch. Ross, with the Spain's State Secretary of Foreign Affairs, visiting Spain last February where it is stated that:

"The State Secretary of Foreign Affairs, Ignacio Ybáñez, met the personal envoy of the United Nations Secretary General for Western Sahara, Christopher Ross, today.

Ambassador Ross informed him of the outcomes of his recent contacts in Mauritania, Algeria and Tindouf.

The State Secretary outlined the priority for Spain, as a member of the UN Security Council and the Group of Friends for Western Sahara, to search for a fair, lasting and mutually acceptable political solution providing for the self-determination of the people of Western Sahara, in the framework of the provisions according to the principles and purposes of United Nations.

Ignacio Ybáñez renewed Spain's commitment in support of facilitation work of the United Nations and Ambassador Ross and confirmed Spanish aid at political, humanitarian and logistic levels" ${ }_{14}$

Also, when receiving UN Secretary-General in Madrid in March. Mr. Ban Ki Moon recalled the role to be played by Spain:

"As a member of the Friends of Western Sahara, Spain is an integral part of United Nations efforts to resolve that complex situation. I will be visiting the region in the next few days and I thank the Spanish government for its support of this mission." ${ }^{15}$

The unexplained silence is highly regrettable taking into account the fact that Spain is a member of the Group of Friends of the Secretary General on Western Sahara -acting there, supposedly, as a bridge to facilitate an approach between the contradictory positions at stake ${ }^{16}$ - and its commitments

I3 Significantly, the deputy Foreign Minister called on "proportional measures" to allude to the restrictions adopted by Morocco concerning the reduction of civil personnel of MINURSO and financial contribution to UN Programs. See MAP, Press Release, 9 March 2016 (text available electronically at <http://www.maroc.ma/es/news/marruecos-expresa-energicaprotesta-contra-las-declaraciones-del-sg-de-la-onu-sobre-el-sahara > accessed 20 June 2016. in Spanish).

${ }^{14}$ FACM Press Note no. 035, 22 February 2016 (accessed is June 2015, translation by the author). Attention should be paid to the periphrastic construction conceived by Spanish authorities to solve the conflict (Italics added). Moreover, not surprisingly, the visit to Madrid of UN Representative has been preceded - four days before- by the, then, recently appointed Morocco's deputy Foreign Minister, Mr. Bourita, who discussed with the State Secretary Ybañez on Western Sahara Question, among other issues. See FACM Press Note no. 030, I8 February 2016 (accessed 20 June 2016).

is Secretary-General's press encounter with H.E. José Manuel García-Margallo, Minister for Foreign Affairs of Spain, Madrid, Spain, I March 2016 (accessed 20 June 2016). Subsequently, asked by the press Mr. Ki Moon revealed his schedule: "it would be ideal for me to be able to visit all the countries concerning this Western Sahara issue. I wanted to start from Rabat after meeting His Majesty King of Morocco, but we were told that the King was not available at this time. With the consultation of the Moroccan Government, I decided to take a two-step approach. First, I will visit Mauritania, Tindouf, and Algeria, and then at a mutually agreeable time I will go back to Morocco, then I'll try to visit Laayoune and MINURSO [the United Nations Mission for the Referendum in Western Sahara]. This is the current plan. As you know, I'm required to make my report to the Security Council during the month of April so this will be my first time as Secretary-General to visit the region, but as you may know, this is my tenth year - last year as Secretary-General. So, it is important for me to be able to visit even partially, but I will make sure that we will visit." (Ibid.)

I6 In fact, conceived as a small group of UN Member States aimed to play an organized role in trying to bring about a solution to a particular situation, they could enable UN Member States that are not SC members -as it was the case for Spain at the time of its creation in 1993- "to play a significant role in the formulation of Council decisions" (L Sievers, S. 
to questions related to decolonization are constantly present even in official circles; in fact, during these months Spain publicized the "mechanical" procedural Decision adopted last November by the GA Fourth Committee on Gibraltar ${ }^{17}$, and in January 2016 our country welcomed the text on the Malvinas (Falklands) Islands adopted by the Argentinian Ministry of Foreign Affairs, pointing out its similarity with the question of Gibraltar ${ }^{\mathrm{r}}$.

Such mutism is hardly understandable inasmuch as even a reaction could be expected insofar as the Polisario submitted its declaration of acceptance of the First Geneva Protocol of 1977 in June 2015, provoking a strong reaction by the Kingdom of Morocco against the Foreign Office of the Swiss Federation for its supposed condescendence towards the Polisario. ${ }^{19}$

In sharp contrast, among Spanish civil society and NGOs supporting the Western Sahara selfdetermination process ${ }^{20}$, there were many events and even academic and non-academic publications were produced to commemorate the anniversary.

But, of course, there are reasons that could elucidate such official muteness by the Spanish Government.

\section{(B) 40 YEARS AGO: THE MADRID AGREEMENTS AND THE 26 FEBRUARY 1976 STATEMENT}

The Spanish mutism on the Western Sahara Question is not recent. In so far as it was covered by confidentiality (materia reservada) during General Franco's dictatorship, according to Moroccan sources secrecy surrounded Spanish negotiations involving the future of the territory even in July I973, when supposedly an agreement might have been concluded between the, then, Spanish Foreign Minister, Mr. G. López Bravo, and his Algerian counterpart, Mr. A. Bouteflika, on the upheaval caused by the self-determination process and, the promotion of Polisario Front role in its development ${ }^{21}$. Certainly, although further events, including the visit of UN representatives in 1975, were conducted with transparency, the ICJ proceedings and the launching of the "Green March" in October 1975, forced Spain's Government to behave in an obscure manner again, resulting in the Madrid Agreements of 14 November 1975.

Daws, The procedure of the UN Security Council, (4th ed., Oxford UP, Oxford, 2014), at I48). However, as we will see later, such prominent role has been neglected by Spain (See below, 3).

17 See FACM Communiqué no. 328, I3 November 2015 (accessed 20 June 2016).

I8 See FACM Communiqué no. 004, 6 January 2016 (accessed 20 June 2016).

19 On the relevance of Polisario Front undertakings of 2015 suffice to say that it was one of the evidences taken into account by the Advocate General F. Wathelet in his Opinion of 13 September 2016 (para. I46) to confirm the international legal personality of Polisario in the appeal proceedings related to the GC Ruling of ro December 2015 (See below, 7). On such question, See D. Alland, "Chronique des faits internationaux", RGDIP, (2016), at 8I4, and our contribution "El derecho del pueblo saharaui a la libre determinación y el «derecho de resistencia» frente a la ocupación marroqui”, in Observatorio Aragonés para el Sáhara Occidental (ed.), Sabara Occidental: Cuarenta años construyendo Resistencia (Pregunta, Zaragoza, 2016), 349-355.

${ }_{20}$ A décalage exists between public opinion - mainly in favor of Western Sahara self-determination- and Government -of whatever political color - in this issue, albeit recent surveys reveal a decrease in the interest and support among Spanish public concerning the question.

2I According to Ch. Saint-Prot, "Un conflit artificiel", in Sabara Marocain..., supra n. 8, at 22-23. 
In fact, as the Statement of Principles was publicized - and even registered by Morocco at the UN Secretary-General Office of Treaties ${ }^{22}$ - all the other agreements concluded thereon, were in no way diffused either by the Spanish side, nor by its Moroccan and Mauritanian counterparts ${ }^{23}$. Moreover, the idea of a cession of sovereignty by Spain over the territory of Western Sahara explained in the document was an oxymoron, as it was impossible to act as the "owner" of a territory merely administered according to UN Principles and International rules. Notwithstanding, it must be remembered that GA Res. no. 3458 (XXX), Io December 1975, part B, takes note of the said Declaration - a move that has been echoed by Morocco as a recognition of the legality of the cession - albeit Part A of the same Resolution is totally at odds with such reading and even the references to the self-determination principle contained in both texts seems contradictory to a tacit approval on the sovereignty transfer claimed by $\mathrm{Morocco}^{24}$.

Notwithstanding, according to Spanish diplomatic sources, the way to escape from this "legal and political imbroglio" - according to J.A. Carrillo Salcedo 25 - was the "solomonic" decision adopted just three months later ${ }^{26}$. In fact, on 26 February 1976, the Spanish Government - then, still headed by the francoist politician C. Arias Navarro- issued a statement that constitutes, until now, the official Spanish doctrine on the Western Sahara issue. This document states that:

"In accordance with the provisions of paragraph 2 of the Madrid Declaration of Principles of I4 November 1975, the Spanish Government, as of today, definitively terminates its presence in the Territory of the Sahara and deems it necessary to place the following on record:

(a) Spain considers itself henceforth exempt from any responsibility of an international nature in connection with the administration of the said Territory, in view of the cessation of its participation in the temporary administration established for the Territory;

(b) The decolonization of Western Sahara will reach its climax when the views of the Saharan population have been validly expressed." ${ }^{27}$

It is also well known how controversial such a statement was: as explained, on the one hand, by the refusal of the Spanish Government to denounce the "Madrid Agreements" and, on the other, the character of the decolonization process as unconcluded until a referendum on self-determination

${ }^{22}$ UNTS, vol. $988, \mathrm{I}, \mathrm{n}^{\circ}$ I4450, 1975.

${ }_{23}$ Those secret Annexes - they were known through its publication by Spanish newspapers in 1978- included the continuing participation of Spain in the exploitation of Sahrawi phosphates (Fosbucráa), technical cooperation, and, specially, the accession of Spain to Sahrawi fisheries, among other issues.

24 Inasmuch, the absolute nullity and voidness of 1975 Madrid Agreements as opposed to jus cogens rule on selfdetermination was commonly shared at the time among Spanish doctrine. Per omnia See J.D. González Campos, L.I., Sánchez Rodríguez and P. Andrés Sáenz de Santa María, Curso de Derecho internacional público, vol. I, (Servicio de Publicaciones de la Universidad de Oviedo, Oviedo, 1983), at 6r9.

25 J.A. Carrillo Salcedo, "Libre determinación de los pueblos e Integridad Territorial de los Estados en el Dictamen del Tribunal Internacional de Justicia sobre el Sahara Occidental", 39 REDI, (1976-I), at 45.

26 "An intermediated way" according to Villar, supra n. 4, at 32.

27 Letter dated 26 February 1976 from the Permanent Representative of Spain to the United Nations addressed to the Secretary-General, UN Doc. A/3I/56-S/ug97, 26 February 1976 (original Spanish). For the printed text, see Official Records of the Security Council, Thirty-first Year, Supplement for January, February and March 1976. It must be remarked that Spanish Permanent Representative at the time was Ambassador J. De Piniés, who had written two books on these issues. See La descolonización del Sábara: Un tema sin concluir (Espasa, Madrid, 1990) and La descolonización española en las Naciones Unidas (Guinea Ecuatorial, Fernando Poo y Rio Muni, Ifni, Sabara Occidental, Gibraltar y las Naciones Unidas) (Centro de Estudios Políticos y Constitucionales, Madrid, 200I). 
might be held in the territory, showing the ambiguity of the Spanish policy on the issue, and providing the opposition political forces with a "weapon" employed thereafter in the Spanish internal political arena ${ }^{28}$. Anyway, the most significant point in the Declaration resides in its last paragraph, where the Spanish Government fixed its position concerning the interrupted self-determination process of Western Sahara, and -according to it - the term supposedly fixed to end the decolonization of the territory, when the "valid" expression of "the views of the Saharan population" would be expressed.

However, in spite of such a "rereading" of the Madrid Agreements ${ }^{29}$,in successive years Spain failed to adopt a really balanced position. In fact, although the Western Sahara issue never altered SpanishMoroccan relations, its relations with the legitimate representative of the Western Saharan people the Polisario Front - were always limited. In fact, low level relations were established with the Polisario in 1979 with the opening of a bureau (Delegación) in Madrid without diplomatic status and as a mere "National Liberation Movement recognized by the United Nations" ${ }^{\circ}$. This nuanced position of the Spanish Government remained even with the accession to power by the Socialist Party in October 1982 -despite its closer relations with the Polisario ${ }^{31}$. Albeit, further, incidents on the Western Saharan seashore ${ }^{32}$, moved the Government of Mr. F. Gonzalez to close the Madrid bureau in 1985, although it was reopened in 1989. This unofficial relation remains until now.

Certainly, not only has Spain sustained an ambiguous position on the issue. We must also remember that even the United Nations General Assembly showed a weak and interrupted support to the legitimate aims of the Western Saharan people to solve the conflict according to the principle of self-determination of peoples. In fact, in these forty years only two Resolutions were adopted condemning the "persistent occupation" of the territory by Morocco and urging it to leave"3.

28 M. Hernando de Larramendi, "La cuestión del Sáhara Occidental en la política exterior española”, in I. Barreñada and R. Ojeda (eds.), Sabara Occidental. 40 años después (Libros de la Catarata, Madrid, 2016), at 265.

29 According to J.C. Pereira, "España en el mundo", in J. Canal (ed.), España. La búsqueda de la democracia (Taurus, Madrid, 2016), at I49.

30 In fact, such limited recognition does not cover the treatment of Polisario as the only and legitimate representative of Sahrawi people" (Villar, supra n. 8, at 66). On these issues see J. Soroeta Liceras, International Law and the Western Sabara Conflict (Wolf, Oisterwijk, 20I4).

31 In autumn 1976, in a significant political move, the leader of Socialist Party, Mr. Felipe González, paid a visit to Tindouf Refugee Camps (see Hernando de Larramendi, supra n. 29, at 266). Even, at this time several joint statements were adopted between the Socialist Party, the Polisario Front, and the Algerian FLN on the Western Sahara issue (See A. Marquina Barrio, "El conflicto del Sahara y la Cooperación Global del Gobierno español con Argelia y Marruecos", 4 Revista de Estudios Internacionales (1983), 758-759).

32 See below, 5 .

33 They were GA Res. 34/37, 2I November 1979, and 35/19, II November 1980. For Moroccan authors and sympathizers such scarce activity would reveal the declining support to self-determination of the territory, even insisting on a supposed "formal recognition" of the 1975 Agreements by the GA Res. 3458 (XXX) B, ro December 1975 (See Cara, "Souveraineté de Maroc sur le Sahara", supra n. 4, at 150); in fact, this Part B is preceded by a Part A diametrically opposite and claiming for self-determination of the territory: the two were the result of irreconcilable positions in the UNGA in a typical "Cold War" context (Franck, supra n. 5, at 717-719). On the contrary, as has been pointed out, the fact that international community continues to refuse to recognize Moroccan annexation proves the continuous validity -albeit isolated- of such pronouncements by UNGA (See M. Dawidowicz, "Trading fish or human rights in Western Sahara? Self-determination, non-recognition and the EC-Morocco Fisheries Agreement", in D. French (ed.), Statebood and Self-determination. Reconciling Tradition and Modernity in International Law, (Cambridge UP, Cambridge, 20I3), at 272). Anyway, in I990, the 
(C) FRIEND OR FOE? AN ABSENT FACILITATOR...

Contrary to its role as de jure administering power, Spain has constantly eluded its responsibilities; certainly, with no requirements coming from the United Nations bodies. Even, the usual participation of Spain before the sessions of the Fourth Committee is restricted to the sole questions of Gibraltar, excluding any participation when the Western Saharan issue is debated ${ }^{34}$. It is well known that such behavior has allowed the progressive emergency of the oxymoron of "de facto administering power" commonly attributed to Morocco in the overrated "Corell Report" of $2002^{35}$. And that's the reason why Morocco and its supporters maintain their thesis about the extinction of the self-determination process of the territory.

As for the implication of Spain as a member of the "Group of Friends of Western Sahara" - as the sole non-permanent member of the $\mathrm{SC}$ - there have been no significant results in his involvement. Certainly, Spain constantly claims that he is participating "directly and actively" in the negotiations leading to the elaboration of the draft Resolution" on MINURSO's mandate renewal ${ }^{6}$. But, in fact, such a presumed active implication is always limited to share the views expressed inside it by "key actors" - according to Spain (i.e. United States, and, mainly, France ${ }^{37}$ ), whose Moroccophylia is undisputed. In fact, as has been rightly putted, in spite of his presence thereon, "throughout these years Spain has been totally unable to adequately remedy the weakness and abandonment that resulted from the Madrid Agreements" ${ }^{8}$.

Not surprisingly, even when acceding to a non-permanent seat at SC in 2003-2004 and nowadays (2015-2016), the Spanish presence at this UN body entrusted with primordial responsibility on peace and security issues, was elusive concerning the Western Sahara conflict. In fact, in 2000's as a nonpermanent member of the SC -heading at this time the UN body - it stated that:

General Assembly reaffirmed that the question of Western Sahara was "a question of decolonization which remained to be completed by the people of Western Sahara"; although-as has recently been pointed out - strictly speaking it is not properly a question of decolonization but of military occupation, notwithstanding the fact that it entails a breach of the right of selfdetermination of Sahrawi people (See M. Hebié, "Was There Something Missing in the Decolonization Process in Africa?: The Territorial Dimension", 28 Leiden JIL (2016), 529-556, at 533).

34 Sometimes, the abstention of Spain in the vote concerning the question has been explained. See FACM Communiqué, 20 October 2004, in Actividades, Textos y Documentos de la Politica Exterior Española, 2004, at 941.

35 UN Doc. S/2002/16r. The Report made by the Swedish diplomat $-H$. Corell, then under Secretary general and head of the UN Legal Department- has contributed to the mystification of the role of Morocco in the conflict. Spain, in fact, has attached to this legal opinion a relevance as confirming -in its view- the powers exercised by Morocco (See Government's Answer to a parliamentary question concerning the legal basis of the presumed international legality conferring to Morocco the condition of Administering Power of Western Sahara, 15 November 2005, in Actividades, Textos $y$ Documentos..., 2005, at 1062). A recent critical approach concerning this document and its implications in R. Rodríguez Magdaleno, "La explotación de los recursos del Sahara Occidental", in Sabara Occidental. Cuarenta años..., supra n. 20, 235256.

36 Appearance of Ministry of Foreign Affairs, Mr. J.M. García-Margallo, before the Plenary of the Senate, 24 April 2or2, GCOJ (BOCG), no. I4, in Actividades, Textos y Documentos..., 20I2, at 459.

37 See Appearance of Foreign Minister, Mr. M.A. Moratinos Cuyaubé, before the Foreign Affairs Commission of the Congress of Deputies, 9 March 20I0, in Actividades, Textos y Documentos..., 2010, p. 353. In fact, many criticism surrounded specifically the activities of the Group of Friends of Western Sahara, inasmuch as usually they didn't allow other SC members to contribute in the drafting of the texts subject to approval before the Council. See Sievers, Daws, supra n. I7, at I49.

38 X. Pons Ràfols, "Spain in the United Nations: Sixtieth Anniversary”, ig SYbIL (20I5), at II5. 
"Spain has always had a policy of constructive neutrality and of not imposing solutions on the parties. We have spared no effort, as an interested party to the conflict as well as in our capacity as President of the Council, to achieve the greatest possible consensus" 39

More recently, the official program submitted in January 2015 by the Spanish Ministry of Foreign Affairs related to its future work within the SC indicated that Western Sahara is one of the issues to be sustained by Spanish diplomacy. According to such a document:

"Spain's historic role, the wellbeing and expectations of the Sahrawi people, and our good neighbourly relations with Morocco and Algeria lead us to favour a fair, lasting and mutually acceptable political solution including the free determination of the people of the Western Sahara, within the framework of UN Charter principles, as established by the SC in its resolutions." ${ }^{40}$

However, one year later, there was little to show for such a promising declaration. In fact, the main results were summarized by Spain in these words:

"Spain has continued to support UN efforts to achieve a political, fair, lasting and mutually acceptable solution that will provide for the self-determination of the people of Western Sahara, in the framework of arrangements that are consistent with the aims and principles of the UN Charter. Among other aspects, this support consisted of providing the Secretary General's Personal Envoy with a Spanish Air Force aircraft to facilitate his travel, and providing the necessary funding for a security coordinator to complement the UN structure in security issues in Tindouf.

Spain emphasizes the need to maintain the international financial support indispensable to ensure the continuity of essential humanitarian projects in the camps and has made major contributions in this respect; thus, Spain was the leading bilateral donor in 2015." ${ }^{11}$

In fact, the humanitarian aid to refugee camps in Tindouf through voluntary contributions to fund food programs - urged by a new subsection introduced in point II of the SC Res. 22I8 (20I5), 28 April 2015- was the only significant result of Spain's participation ${ }^{42}$. Certainly, a poor outcome insofar as such a dimension is, undisputedly, the only long standing and consistent trend in the Spanish action

39 Intervention before the SC by Spain's Permanent Representative, Mr. I. Arias, 3I July 2003, S/PV.480I, p. 5 (Italics added). This "constructive neutrality" was apparently dropped with the access to power of Socialist Party in 2004 claiming for an "active implication in the solution of the conflict" (M. Hernando de Larramendi, I. González González and B. Ataola Piazza, "El Ministerio de Asuntos Exteriores y la política exterior hacia el Magreb", in M. Hernando de Larramendi and A. Mañé Estrada (eds.), La Política Exterior Española hacia el Magreb. Actores e intereses, (Ariel-RI Elcano, Barcelona, 2009), at 87). In fact, during the first months of the first Government of Mr. J.L. Rodríguez Zapatero an intense and "active diplomacy" was deployed by the Prime Minister, the Foreign Affairs Ministry, Mr. M.A. Moratinos, and the Secretary of State of Foreign Affairs, Mr. B. León, including a visit of the last one to Tindouf in June 2004, and provoking a serious concern in Moroccan circles (See M. Larbi Messari, Las relaciones difíiiles. Marruecos y España (Almuzara, Córdoba, 2009), at I33). However, no significant results derived from this approach that was quickly forsaken (See below, 6).

40 Programme. Spain 2015-2016 Non-Permanent Member of the United Nations Security Council, Ministry of Foreign Affairs and Cooperation, January, 2015, at I2 (accessed Io September 2016). In spite of this announcement, writing on the work to be developed inside the SC a senior official of the Spanish Foreign Affairs Ministry did not deserve any significant mention to Western Sahara (See F.J. Sanabria Valderrama, "Recuerdos de campaña y apuntes al natural de los quehaceres en el quinto mandato de España en el Consejo de Seguridad (2015-2016)", in X. Pons Ràfols (ed.), Las Naciones Unidas desde España. 70 Aniversario de las Naciones Unidas. 60 aniversario del ingreso de España en las Naciones Unidas (ANUE, Barcelona, 2015), 489-499. Otherwise, although the second part of the book is devoted to the role of Spain during 60 years of UN membership, it does not make any reference to the issue.

${ }_{41}$ Spain in the United Nations Security Council: Review of 2015 and Priorities for 2016, Ministry of Foreign Affairs and Cooperation, at 14 (accessed io September 2016).

42 See intervention before the SC of Spain's Permanent Representative, Mr. R. Oyarzun Marchesi, 28 April 20I5, S/PV.7435, at 4 . 
with regard to Western Sahara, but really owing to the pressure from public opinion and the significant contributions by Autonomous Communities, Local entities and Spanish civil society ${ }^{43}$.

Nevertheless, the limits of Spain's participation in the SC were revealed along the last Spring when successive meetings of the SC tried unsuccessfully to solve the previously mentioned MINURSO crisis ${ }^{4}$ - and, specially, on April, when deploring the adoption of SC Resolution 2285 (2016), 29 April 2016, by a majority of votes - instead of the usual unanimity- our country resorted to the familiar ritornello on the "efforts on helping the parties to reach a just, lasting and mutually acceptable political solution" and refrained to address any of the serious problems concerning the issue and linked, specially, with the Moroccan measures on the reduction of MINURSO staff adopted after the previously mentioned Bir Lehlu incident ${ }^{45}$.

\section{(D) ...RELUCTANT TO CONSIDER EVEN HUMAN RIGHTS ISSUES CONCERNING THE TERRITORY...}

As for Spain, even serious developments on the situation of human rights concerning Western Sahara have lacked of a real gusto. In this sense, the crisis concerning the hunger strike of Sahrawi activist Aminetu Haidar is a case in point, and where the hesitancy of the Spanish Government revealed a sharp contrast with other international positions ${ }^{46}$.

43 On these issues See S. Ruiz Seisdedos, M.L. Grande Gascón, "La cooperación española con la población saharui", in Sabara Occidental. 40 Años después, supra n. 29, 277-292.

44 In fact, six SC informal meetings were held (I7 and 25 March, 7, I3 and 27 April 2016) -and even one of them through the Arria Formula (26 April 2016) - to solve the crisis created by Morocco's decision - subsequent to Bir Lahlou incidenton the reduction of MINURSO civil staff, and "elements for the press" were provided on 25 March 2016 concerning MINURSO. As for the Arria meeting on 26 April 2016, it was convened by Angola and Venezuela to know on the African Union views on the conflict. This informal meeting was not usual concerning Western Sahara, although in 1995 and 2000 several meetings were held according to such a formula. See Sievers, Daws, supra n. I7, at 78-9I.

45 See intervention before the SC of Spain's Permanent Representative, Mr. R. Oyarzun Marchesi, 29 April 20r6, S/PV.7684, at 6-7. In sharp contrast with the pusillanimity of Spanish position, the permanent representative of New Zealand -who abstained in the vote- didn't spare critics to the situation and showed in a precise way the real scope of the problems when he stated that: "we have seen, again, the preparation of a text in a Group of Friends whose composition does not reflect the span of perspectives that exists on the Western Sahara, neither among the protagonists on this issue nor on the Council, and an unwillingness to accept modest amendments on a text that deals with an issue of importance to the whole Council, indeed to the whole United Nations membership. In New Zealand's view, today's resolution falls short of what the Council should be doing to discharge properly its responsibilities on the Western Sahara. A resolution that truly reflected the gravity of the current crisis over the United Nations Mission for the Referendum in Western Sahara (MINURSO) and the magnitude of the challenge inherent in the full discharge of the MINURSO mandate should have done the following things. First, the resolution should have stated the reality that the expulsion of the civilian component had seriously compromised the Mission and its ability to discharge its mandate. These facts have been repeatedly stated by the Secretariat in its briefings to the Council over the past month. Secondly, the resolution should have called for the immediate restoration of the full functionality of the Mission and provided for the Council's continued engagement to ensure that a return to full functionality is achieved in the near future... Finally, in our view, every member of the Security Council must reflect on the broader implications of the current episode over MINURSO's deployment for the Council's stewardship of its peacekeeping operations globally" (Intervention before the SC of New Zealand's Permanent Representative, Mr. G. Van Bohemen, 29 April 2016, S/PV.7684, at 3).

${ }_{46}$ The Spanish position was more astonishing if we take into account the reaction of the Swedish Presidency of EU Council - that issued a Declaration on the issue the II December 2009- or neighborhood countries. In fact, just few months later, the Italian Government endorsed a Resolution approved by the Chamber of Deputies (Risoluzione no. 7-00338, 
Again, when the incidents of Gdeim Izzik in autumn 2010 Spain although deploring them, showed an unexpected restraint, invoking the need to behave with "prudence". ${ }^{47}$ Further, the flow of Sahrawi people escaping from Moroccan repression after the forceful dismantlement of the camp between January 20II and August 20I2, give a chance to Spain to alleviate the situation on the grounds of the right of asylum. Nevertheless, the applications submitted were rejected by the Spanish authorities and confirmed by the High National Court as unfounded. However, the decision to expel them to Morocco was suspended as the applicants introduced requests for provisional measures before the ECHR, which were adopted, urging Spain to refrain from deporting the applicants until such time as the judgment in progress became final or the Court gave a further decision in the case. Finally, the European Court found the violation by Spain of arts. 2, 3 and I3 of European Convention on Human Rights. ${ }^{48}$.

Otherwise, in March 2013 when the SC was seriously considering attributing a mandate to MINURSO on human rights questions, it was for Spain - supporting the salient French Government position - to militate against it, ${ }^{49}$ albeit it is well known that peace-keeping operation mandates currently cover the protection on human rights ${ }^{5 \circ}$.

Moreover, when in February 2014 a Moroccan military tribunal delivered life sentences to Sahrawi activists - presumably involved in the murder of Moroccan police agents in Gdeim Izzik - nonofficial reaction was adopted by Spanish Government. In fact, in a calculated move, the ominous

20 July 20I0) concerning Western Sahara and asking for the freedom of expression and "the right to enter one's own country as sanctioned by article I2 paragraph 4 of the International Covenant on Civil and Political Rights", directly linked with the previous situation of Mrs. A. Haidar (See "Italian Practice related to International Law", 20 IYIL (20I0), at 447-448).

47 Appearance of the Minister of Foreign Affairs and Cooperation, Mrs. T. Jiménez García, before the Plenary of the Senate, to answer the parliamentary question submitted by Mr. F.J. Tuñón San Martín (Joint Political Group), on the measures to be adopted by the Government concerning the harsh attacks of Moroccan Army in the Camps of El Aaiún, (GCOJ (BOCG), no. I00, 16 November 2010; in Actividades, Textos y Documentos..., 20I0, at 444).

48 ECHR, Decision of 24 April 2014, A.C. and others v. Spain, Application no. 6528/Ir.

49 Previously, Spain was supposedly in favor to introduce such a provision. In fact, in April 2012 through its participation in the Group of Friends of Western Sahara "defended in that forum the desirability of introducing control mechanisms for the respect of human rights in the mandate of MINURSO; a position shared by most of the countries that are part of that group" (Appearance of Ministry of Foreign Affairs, Mr. J.M. García-Margallo, before the Plenary of the Senate, 24 April 2012, GCOJ (BOCG), no. I4, in Actividades, Textos y Documentos..., 2012, at 459. Translation by the author). Nevertheless, the same day the Resolution 2044 (20I2), unanimously adopted, excluded such an option that in words of Morocco's permanent representative implied the refusal of the Council "to consider broadening the mandate to include matters that are irrelevant to the functions and nature of the Mission" (S/PV.6758, at 4-5). In the case of Spain, the reversal of its position - according to the acting deputy Permanent Representative before the United Nations, Mr. J.M. González de Linares- was related to the fact that human rights issues must not be treated before the Security Council, but properly in the Human Rights Council. In his opinion "there was a gross mistake by the Obama Administration to purport to submit this issue before the SC" (conversation with the author at Spain's Permanent Representation to UN, New York, 9 October 2014). In spite of this, later in some responses to parliamentary questions the Government stated that "Spain, as a member of the Group Friends of Western Sahara, ... will support consensus proposals discussed inside" to include "monitoring and protection human rights" (GCOJ (BOCG), no. 479, I7 June 20I4, in Actividades, Textos y Documentos..., 2014, at 642 and 646. Italics added).

so See J. Perea Unceta, "Los mandatos de las operaciones de mantenimiento de la paz de las Naciones Unidas en materia de protección de los derechos humanos: inclusión y problemática", in A.G. López Martín (ed.), Nuevos retos y amenazas a la protección de los derechos bumanos en la era de la globalización (Tirant lo Blanch, Valencia, 2016), 173-208. 
silence of Spain's authorities was balanced by a subsequent Communiqué where our country, in an implicit connection with the previous trial:

"[...] welcomes the decision taken last March I4 by the Government of Morocco to present a bill to Parliament to modify the jurisdiction of military courts so that they could not try civilians.

The adoption of a legislative amendment to limit the military jurisdictional scope and adapt it to the constitution of $201 \mathrm{I}$ and international human rights standards internationally accepted, together with the new provisions on the competence of the National Council of Moroccan Human Rights to receive and handle individual complaints, would be a positive step in improving respect for human rights and freedoms by Morocco."

Even so, the quick conclusion by Spain of the Treaty on Arms Trade, of 2 April 2013 and its relevant commitments on human rights has no implications concerning the fruitful transactions with Morocco. In fact, the successive complaints submitted by Spanish NGOs before the Trade Ministry had no results ${ }^{52}$.

In spite of the Spanish Government position, the violation of human rights in Western Sahara has been considered by Spanish Courts. In fact, in 2014 three relevant decisions were adopted by the Central Instruction Judge no. 5 and the National High Court (Criminal Chamber) where Spanish jurisdiction was affirmed in connection with these acts; among them, more specifically, the Order of 4 July 2014 of the National High Court — related to the events of Gdeim Izzik - founded Spanish jurisdiction on the condition of our country as continuing de jure administering power in Western Sahara. Albeit surrounded by controversy, such affirmation has had unexpected effects in other judicial proceedings still in progress ${ }^{33}$.

\section{(E) ...AND, APPARENTLY, UNWORRIED ABOUT INCIDENTS RELATED TO WESTERN SAHARA}

\section{TERRITORY AND, SPECIALLY, ITS MARINE AREAS}

The indifference expressed by Spain on the fate of Western Sahara is not in line with other issues concerning this territory where Spain's interests are really at stake. In fact, Spain has not disregarded Western Sahara, mainly when the exploitation of its marine resources is concerned.

This strong interest was very clear just after the relinquishment of the territory. In fact, as it is well known, the reward for such a move - according to the secret annexes of 1975 Madrid Declaration

51 FACM Communiqué no. 073, I6 March 2014 (accessed is September 2016, translation by the author).

52 On the legal implications related to human rights on this matter and the disappointing Spanish practice, See J.D. Janer Torrens, "Política europea de control de las exportaciones de armas convencionales y seguridad humana: mecanismos para fomentar el respeto de los derechos humanos", 68 REDI (2016-I), 49-7I. As for the griefs submitted by Spanish NGOs concerning Morocco and Western Sahara, See L. Mangrané Cuevas, E. Melero Alonso, "Exportaciones de material de defensa español a Marruecos: Acciones legales de denuncia”, in F. Palacios Romeo (ed.), El derecho a la libre determinación del pueblo del Sábara Occidental. Del ius cogens al ius abutendi (Aranzadi, Cizur Menor, 20I3), 29I-335.

53 On the implications of this Ruling, See below, 7. For an analysis of these Judicial Orders, See F. Briones Vives, "La situación legal del Sahara Occidental en la doctrina de la Audiencia Nacional”, in Sabara Occidental: Cuarenta años..., supra n. 20, I25-I45; N. García Sanz, M. Ollé Sesé and S. Ruiz Calvo, "Comentario al Auto de Procesamiento del Juzgado Central de Instrucción $n^{\circ} 5$ de la Audiencia Nacional en el marco de la causa incoada por el genocidio contra el pueblo saharaui", Ibid., I03-I23; C. Teijo García, 67 REDI (2015-I), I93-I97, and our contribution "Pasado, presente... ¿y futuro? del respeto de los derechos humanos en el Sáhara occidental: Apuntes desde España”, Ordine Internazionale e Diritti Umani, (2015), $267-270$. 
of Principles - was the access to Sahrawi marine areas ${ }^{54}$. Afterwards, the attempts by the Spanish Government to guarantee permanent access of Spanish vessels to Sahrawi fisheries concluded with two successive agreements -in 1979 and 1983- where Spain apparently recognized the "jurisdiction" of Morocco over Western Sahara marine areas 55 . Probably, it is not accidental that when these agreements were in force some maritime incidents - many of them not yet clarified - took place in the waters of Western Sahara; in fact, in one of them in 1985, the Polisario Front alleged that the area was a "war zone" and claimed its responsibility acting "in self-defense of its own territory"s6.

In the same way, the accession of Spain to the, then, European Communities was succeeded by the conclusion in 1987 of an agreement on Fisheries that followed the same path -with ambiguous references to waters under Morocco's "sovereignty or jurisdiction" - followed by new agreements in 1992, 1995 and 1999. Notwithstanding, several problems arose on the implementation of the latest agreement, leading to its non-renewal for five years, although a new agreement was further concluded in 200657 .

Another good illustration of the "apathy" of Spain concerning the fate of Western Sahara lies in its apparent misconception of the territorial application of treaties. Such a gesture seems to be very hypocritical, certainly not in line with the common practice of States and particularly Spanish practice. From this point of view, suffice it to remember how zealously Spain defends the strict extent

54 J.M. Sobrino Heredia, "Les relations de pêche entre l'Union Européenne et le Maroc: La recherche d'un nouveau modèle d'accord de pêche", I3 Espaces et Resources Maritimes (1999-2000), at 238, footnote I4. It is interesting to note that the consolidation of Morocco's misappropriation of Sahrawi waters pitch upon some obstacles: initially, the temporary division of such areas with Mauritania. Years after, the withdrawal of the OAU - now African Union- since 198I, impeding to "fortify" them with the conventional developments related to marine and coastal management produced there (e.g. Maputo Convention of Nature and Natural Resources 2003 or UNEP Convention for Cooperation in the Protection, Management and Development of the Marine and Coastal Environment of the Atlantic Coasts of the West, Central and Southern Africa Region 198I - Abidjan Convention - and its Protocol). See S. Idllalène, "Integrated Coastal Zone Management in Morocco: From Improvised Norms to Formal Law", 3I The International Journal of Marine and Coastal Law (2016), at 178-I79.

55 After a failed agreement of cooperation on fisheries in 1977, the two States reached an Interim Protocol on Fisheries, made in Rabat on 29 June 1979 (SOJ (BOE), no. 253, 22 October 1979), prorogated until 1983 , and succeeded by the later Agreement on Cooperation in Marine Fisheries of I August I983 (SOJ (BOE), no. 243, II October 1983). According to J.D. González Campos, taking into account its main provisions and Annexes, this one achieved the "implied recognition by Spain of Moroccan sovereignty over the entire Western Sahara" (Práctica española de Derecho internacional público", 4I REDI (1989-2), at 569).

56 Western Sahara Democratic Republic, Communiqué of 23 September 1985; reproduced in the newspaper El País, 24 September 1985 (accessed 25 May 2016) The imminent reaction of Spanish government led to closure of Polisario's bureau in Madrid. Many years later, Spanish fishermen dead in the attack were recognized as "terrorism victims" by the Royal Decree no. 249/20II in an inconclusive characterization of the incident. See F. Palacios Romeo, "El Frente Polisario bajo el estatuto de Movimiento de Liberación Nacional. En torno a la vulneración de derechos fundamentales, estrategia de criminalización y banalización del hecho terrorista", in El derecho a la libre determinación del pueblo del Sáhara Occidental..., supra n. 59, III-160.

57 On these issues, See S. Ihraï, "Le Non-renouvellement en 200I de l'accord de pêche Maroc/Union Européenne", 6 ADMer (2003), I35-150; I. González García, "Los acuerdos comunitarios de pesca con Marruecos y el problema de las aguas del Sáhara Occidental", 36 REDE, (2010), 521-563, and J. Soroeta Liceras, "La délimitation et l'exploitation des espaces maritimes du Sahara Occidental, un caillou (de plus) dans la chaussure des relations Espagnole-Marocain”, in J.M. Sobrino (ed.), Sûreté maritime et violence en mer (Bruylant, Brussels, 20II), I3I-I44. Notwithstanding, exceptionnally, a SpanishMoroccan Interim Protocol was concluded after the Prestige disaster in 2002, where 64 galician vessels were "graciously" authorized by "his Majesty Mohamed VI" to fish in Moroccan waters -Western Sahara included (See E.M. García Rico, "Las preguntas formuladas al Gobierno por J. A. Labordeta sobre la autorización a barcos gallegos para pescar en aguas 'del antiguo Sáhara español'. Comentarios a una respuesta incompleta", 55 REDI (2003-I), 5II-515). 
related to the application of $17 \mathrm{I} 3$ Treaty of Utrecht on the issue concerning the cession of Gibraltar to the United Kingdom, despite the fact that the borders of this enclave have never been established. On the contrary and surprisingly, Spain has never been worried about the application ratione loci of successive agreements on Fisheries concluded with Morocco - bilaterally or through the European Community/European Union - in spite of the existence of a territorial delimitation dating from colonial times, easily extensible to marine areas between Morocco and Western Sahara, according to international practice. Nevertheless, Spain supports the "unpredictability" maintained by the European Commission about the marine areas concerned by Fisheries agreements.

In fact, according to it, the terms endorsed by the 1987 Fisheries Agreement between EEC and Morocco:

"[...] applies to the waters over which the Kingdom of Morocco has sovereignty or jurisdiction which it describes as 'Morocco's fishing zone', but contains no fuller geographical definition. The Commission is unable, therefore, to comment on the geographical demarcation of that zone, in particular in relation to the waters off the Western Sahara"s.

Despite such an apparent lack of precision maintained in successive Agreements, on explaining the situation derived from the 1999 Agreement, the Commission sustained that the reference to "Morocco's fishing zone" did not imply any interference to the legal condition of Western Sahara waters, regulated by the International Law and UN Resolutions, as supported by the European Union. 59

Such indifference was maintained even when the new Protocol of 2013 was negotiated, as no specific references to its limits of extent were considered, as revealed by the answer of theEU Council:

"On I4 February 20I2, the Council adopted a decision authorizing the Commission to open negotiations on behalf of the European Union for a new protocol to the Fisheries Partnership Agreement with the Kingdom of Morocco. That decision follows the decision of the European Parliament on I4 December 2orr not to give its consent to an extension of the previous protocol to the Fisheries Partnership Agreement.

The negotiating directives envisage provisions in the new protocol ensuring compliance with international law and appropriate reporting by the Moroccan authorities on the socioeconomic impact of implementation of the Protocol."60

The violation of International Law certainly gives rise to controversy in the case of unclear clauses related to the territorial application of treaties, insofar as at first sight and in conformity with international rules ${ }^{61}$, such an application covers only the State's territory (i.e. internationally

58 Written Question no. 37/9I by Mrs Barbara Simons $(S)$ to the Commission of the European Communities (I February 199I), Answer given by Mr. M. Marin on behalf of the Commission (I8 March I99I), OJ no. C 2IO, I2 August I99I, at I4; cited in P. Andrés Sáenz de Santa María and R. Riquele Cortado, "El Sahara Occidental en las relaciones UEMarruecos", in A. Remiro Brotóns (ed.), Unión Europea-Marruecos ¿Una vecindad privilegiada? (Academia Europea de Ciencias y Artes, Madrid, 2012), at 546.

59 European Parliament, Debate i5 February 200I; Ibid, at 547.

60 Answer given by the Council to a question by Portuguese (GUE) MEP Joao Ferreira, 2012.

${ }_{61}$ Art. 29, Vienna Convention on the Law of Treaties, II55 UNTS 33I (adopted 23 May 1969, entered into force 27 January 1980). 
recognized), excluding other areas and namely non-autonomous territories or foreign territories under military occupation. In the case of the EU, such a formalistic approach, founded on these rules explains why it does not consider either contributing or to recognize, or to cooperate, in the alleged unlawful exploitation of Western Sahara resources.

Anyway, the opposition of the European Parliament to the approval of the Fisheries Protocol in 20II was finally the result of mixed feelings of MEPs, where concerns about disrespect for UN principles were not primordial ${ }^{62}$. In fact, indifference about fishing activities, and ecological interests were essentially at stake. Then, a hypothetical non-renewal of the Protocol now in force - regardless of its judicial avatars ${ }^{6}$ - must not be discarded, specially taking into account the increasing awareness in the public opinion of EU Member States about sustainability and resilience of fisheries worldwide; an interest not yet well guaranteed in the contemporary Common Fisheries Policy Reform of 2013 and its related conventional developments ${ }^{64}$.

Certainly, those moves did not averted some conflicts with Morocco in connection with the delimitation of continental shelf near to Canary Islands, insofar as Spain adopted some measures related to its extent and concerning the prospection of oil and gas resources, as a way to avoid a negotiation which entails directly over the Western Sahara issue ${ }^{65}$.

(F) RECENT TIMES: A PATIENT, ALBEIT INTENSE, APPROACH TO MOROCCAN POSITIONS

Despite its declared "constructive neutrality", some moves by the Spanish Government reflect a "benevolent neutrality" concerning Morocco more precisely. In this regard, statements made by the former Prime Minister, Mr. J.L. Rodríguez Zapatero, were considered at the time by opposing

${ }_{62}$ Anyway, on the relevance of Western Sahara Question on the issue, See J. Smith, "Fishing for Self-Determination: European Fisheries and Western Sahara - The Case of Ocean Resources in Africa's Last Colony”, 27 Ocean Yearbook (2013), 267-290.

63 See below, 7.

${ }^{64}$ As for this future scenario, See E. Self, "Who Speaks for the Fish? The Tragedy of Europe's Common Fisheries Policy?", 48 Vanderbilt JTL (2015), 577-607. On a totally opposed view, See J.M. Sobrino Heredia and G.A. Oanta, "The Sustainable Fisheries Partnership Agreements of the European Union and the Objectives of the Common Fisheries Policy: Fisheries and/or Development?", I9 SYbIL (2015), 6I-85), who describe an idyllical scenario coming specially from the new agreements concluded-EU-Morocco included- and where no attention is deserved to the Western Sahara issue.

65 Since 1988 on several occasions Spain has recognized the impossibility to solve the problem, directly linked with the Western Sahara status (See Reply of the Government, GCOJ (BOCG), III Legislature, D, no. 315, at I4830-I4831, in J.D. González Campos, supra n. 56, at 545; Intervention of Foreign Affairs Minister, Mr. J. Piqué, Diario de Sesiones, Senate, no. 44, I6 May 200I). In this context, a Preliminary Presentation submitted by Spain on II May 2009 to the Commission on the Limits of the Continental Shelf was rejected by Morocco through the Letter of I6 May 2009 of Permanent Mission of Morocco to the United Nations to the UN Secretary General. Further, on I7 December 20I4, the Spain submitted to the Commission information on the limits of the continental shelf beyond 200 nautical miles from the baselines from which the breadth of its territorial sea is measured in respect of the area west of the Canary Islands, notwithstanding -in a clear allusion to Western Sahara issue - the "rights of third parties that could be claimed in the future" (See Information provided by the UN Division for the Ocean Affairs and the Law of the Sea, accessed 20 September 2016; Government of Spain, Presentación parcial de datos e información sobre los límites de la Plataforma Continental de España al Oeste de las Islas Canarias, conforme a la Parte VI y el Anexo II de la Convención de las Naciones Unidas sobre el Derecho del Mar, p. IO, (in Spanish, accessed 20 September 2016). On these issues See J. Martín y Pérez de Nanclares, "Plataforma continental ampliada al oeste de las Islas Canarias: presentación española ante la comisión de límites de la plataforma continental”, 68 REDI (2016-I), 219-226). 
political parties as an expression of an about-turn in the traditional official Spanish position on the issue $^{66}$. Anyway, in a more unequivocal way, the full support to the recognition of an "advanced status" for Morocco by the European Union was echoed by Spain's Foreign Minister, Mr. Moratinos Cuyaubé as:

"a strategic commitment by the European Union to the future of North Africa, which can become the best lever of influence to create the horizon of the Maghreb Union and enable a definitive solution, according to the doctrine of the United Nations, concerning the conflict of Western Sahara" ${ }^{7}$

Of course, this quiet but sustained approach was a fact shown more recently in the process leading to the adoption of the recent Spanish Strategy for External Action. In fact, in the preparatory works leading to such document, guided by the experts of the well known Spanish think-tank Real Instituto Elcano, the previous draft suggested that:

"Spain, as a natural bridge between North Africa and Europe, has a strategic interest in the Mediterranean becoming a geopolitical space of its own -with effective multilateral bodies- and in the EU strengthening its support to its southern neighborhood at a time of difficult but encouraging transformations. Spain must deepen its good relations with Morocco and, at the same time, become involved in a balanced way in the attempt to improve relations between all the States in the Maghreb." 68

Then, when analyzing the question of Western Sahara this biased (Moroccopbyle) and State-centered approach gives a coherent perspective of the problem and of the ways to manage it in the future by Spanish diplomacy. In fact, the draft Report states:

"Spain should continue working to achieve a fair and lasting political solution to the decolonization of Western Sahara; which, in addition to historical responsibilities, is connected to values and interests relevant to Spain and its society. The question has suffered a prolonged blockade as a result of two long-term conflicts of difficult solution. One is the clash of Moroccan nationalism with the Sahrawi nationalism and although long ago armed hostilities ceased, the effects of mutual suffering have not disappeared, which is most evident in the Sahrawi party. The other conflict is competition between Morocco and Algeria for hegemony in the Maghreb, reflected in current weak bilateral relations that should be strengthened." ${ }^{6}$

66 It was the case for the statement made by him in Casablanca in April 2004 speaking on the rights of Morocco over Western Sahara, although the reply of the Government to a parliamentary question tried to reduce its political impact. See Answer of the Government to the Question submitted by the Deputy Mr. J.I. Erkoreka Gervasio of the Basque Group, concerning Statements made by the Prime Minister in his trip to Casablanca on 24 April 2004 related to the solution of Western Sahara Conflict (GCOJ (BOCG), no. 42, 24 June 2004, in Actividades, Textos y Documentos..., 2004, at 777). In fact, the reticence of Mr. Rodríguez Zapatero towards self-determination in the Western Sahara was clearly expressed by him on several occasions, even before and during his mandate (See I. Cembrero, Vecinos alejados. Los secretos de la crisis entre España y Marruecos (Galaxia Gutenberg-Círculo de Lectores, Barcelona, 2006), at 99).

${ }_{67}$ Appearance before the Foreign Affairs Commission of the Congress of Deputies, 9 March 20ro, in Actividades, Textos $y$ Documentos..., 20ro, at 350 (translation by the author).

68 Real Instituto Elcano, Executive Summary and Conclusions of the Elcano Report "Towards the strategic renewal of Spain's foreign policy", at 6 (accessed 20 May 2016). For a deeper analysis of this document See L. Mestres, "Does Spain Really Need a Foreign Policy Strategy? More than a Proposal from a Think Tank", I8 SYbIL (2013-20I4), 279-286.

69 I. Molina (ed.), Hacia una renovación estratégica de la política exterior española Elementos para conectar mejor el proyecto colectivo de país con el mundo globalizado (Real Instituto Elcano, Madrid, 2014), at 77 (accessed 20 May 2016, translation by the author). 
Painting the question as a dispute between nationalisms does not seem to be an accurate picture of what is really an unsolved decolonization question -maintained through military occupation - unless it is assumed that the Polisario Front behaves like the UCK in Kosovo, a true separatist movement, (regardless of the support reached by it from Western countries). 
The close connection with another recurrent Moroccan thesis -the "security doctrine" - is also found in another part of the document, where it is stated that:

"In the Sahel it is producing a proliferation of jihadist groups dedicated to organized crime and gangs. In this context, the possibility of a new state populated only by a few hundred thousand non homogeneous inhabitants susceptible to radicalization, is causing concern beyond Maghreb countries."’o

Last but not least, claiming for a "proactive role" of Spain in the settlement of the conflict, the document concludes with an apparently balanced proposal, albeit unequivocally sided to Morocco:

"UN resolutions provide for an agreement between the parties to hold a referendum, and that is also the official Spanish position. However, for the Polisario the referendum should be held to decide on independence, while for Morocco it should be just to confirm a prearranged integration status on its territory. (In this context) Spain could take a more proactive stance and when conditions become favorable, to submit a solution based on a genuine and guaranteed self-government that could satisfy the desires of Morocco and the Polisario Front." ${ }^{\text {T }}$

Is it coincidental that "self-government" - instead of self-determination - solution is heralded by one of the most relevant Spanish think-tanks? What about its connections - and coincidences- with Morocco's Autonomy Plan of 2007 ?

Certainly, a later draft prepared by the FAC Ministry showed a clearer stance on the issue ${ }^{72}$ and the Strategy for External Action finally adopted by the Council of Ministers of Spain - according to the Law no. 2/20I4, of 25 March, on External Action and Service of the State ${ }^{73}-$ on 26 December 2014 upholds such a position, when claiming that:

"The Western Sahara question is still a very sensitive issue to the feelings, interests and values shared by Spaniards. External policy defined to manage this question must take this into account, as well as the international community framework constructed to resolve it. For all of these reasons, Spain maintains a firm commitment to seek a just, lasting and mutually acceptable political solution that envisages the free determination of the Western Sahara people in the framework of the United Nations.

As a member of the Group of Friends, we maintain an active commitment to said solution. Spain defends the central role of the United Nations in the resolution of the conflict and supports efforts of the successive personal envoys of the Secretary General of the United Nations."74.

However, even this statement adopted by the Government lead by the People's Party is a long way from previous statements made public by the representatives of this political formation at a time

$70 \quad$ Ibid.

${ }^{71}$ Ibid. Note that the proposal (italics added) suggests a "self-government" (i.e. autonomy?) -not self-determinationsolution.

72 (Draft) Strategy for External action (Ministry of Foreign Affairs and Cooperation, Madrid, October 20I4), at I07 (in Spanish, accessed 20 May 2016).

73 SOJ (BOE), no. 74, 26 March 2014.

74 Strategy for External Action (in Spanish) (Ministry of Foreign Affairs and Cooperation, Madrid, February 2015), at Io9 (accessed 20 May 20I6, translation by the author). In fact, the Director of the Elcano's Draft recognized that the Final Strategy elaborated by the Ministry had not really included any of the most innovative recommendations of their Report" (Mestres, supra n. 69, at 285-286). Anyway, not surprisingly the account of activities developed according to the Strategy and related to Western Sahara lies exclusively on the humanitarian aid that traditionally benefits the refugee camps (See Annual Report on the Application of the Strategy for External Action (Ministry of Foreign Affairs and Cooperation, Madrid, May 2016), at 79 (in Spanish, accessed 30 September 2016, translation by the author). 
when they were in the opposition. Suffice it to remember the Resolution adopted by the Senate at its behest in 2007 where the Spanish High Chamber requested the Government:

"To defend a fair and definitive solution accepted by all the parties, ...in the framework of the international legality and the legitimate right of Sahrawi people to its self-determination, according to the United Nations Charter and the resolutions of the Security Council"

A solution that could only conclude with - following the same statement-:

"[ $t]$ he full acceptance by the parties of the principle of self-determination of the Sahrawi people, without presupposing, in any case, any right of Moroccan sovereignty over Western Sahara until the Sahrawi people can decide by itself, through a free and democratic referendum"75.

As for the question of the supposed radicalization of some elements of the Polisario Front and its alleged connections with jihadist movements in south Sahara and Sahel regions -one of the claims recurrently sustained by Morocco- Spain occasionally seems to be aligned with these. In fact, on the occasion of the kidnapping of three humanitarian workers in the Tindouf Refugee Camps in 20I2, Spain's Ministry of Foreign Affairs decided at the end of July 2012 to repatriate "voluntarily" all the Spanish personnel working in the camps, arguing that there were "serious risks" for their "security" 6 . Although these measures were subsequently lifted, Spain's authorities sometimes remained attached to these arguments, despite the fact that such presumed links have no empirical support 77.

(G) ALL QUIET ON THE WESTERN SAHARA FRONT?: THE IMPACT OF GC RULING OF DECEMBER, IOTH, 2OI5 AND ITS SUBSEQUENT DEVELOPMENTS

More recently, one of the reasons which explains Spanish restraint concerns the decision of the EU General Court of Io December 20I5, Front populaire pour la libération de la saguia-el-hamra et du rio de oro (Front Polisario) c. Consejo de la Unión Europea (T-5I2/I2), annulling partially the Council Decision 2012/497/EU of 8 March 2012 on the conclusion of an Agreement in the form of an Exchange of Letters between the European Union and the Kingdom of Morocco concerning reciprocal liberalisation measures on agricultural products, processed agricultural products, fish and fishery products, in so far as it approves the application of that agreement to Western Sahara ${ }^{7}$. Much

75 Resolution submitted by the political group of the People's Party at the Senate, no. II4, approved by the Plenary on I7 April 2007 (GCOJ (BOCG), Senate, J, no. 697, at I2, paras. I and 3. Translation by the author. Italics added).

76 FACM, OID Press Communiqué, Madrid, 6 August 2012, in Actividades, Textos y Documentos..., 2012, at 65I. However, the author, as a member of a Spanish Delegation of NGOs sent to Sahrawi Refugee Camps in those days took evidence of the security measures existent therein, after talks with Polisario, Sahrawi Red Crescent, MINURSO and World Food Program officials.

77 See M. Porges, Ch. Leuprecht, "Abstenerse del terror: la paradoja de la no violencia en el Sahara Occidental" (Refraining from Terror: the Puzzle of Non Violence in Western Sahara)", II2 Revista CIDOB d'Afers Internacionals (2016), at 153 .

$7^{8}$ On this Ruling see Th. Fleury Graff, “Accords de libre échange et territoires occupés. À propos de l'arrêt TPIUE, IO décembre 2015, Front Polisario c. Conseil", RGDIP (2016), 263-29I; R Gosalbo Bono, "El Frente Polisario, las normas del Derecho internacional y el derecho de la Unión Europea", 53 RDCE (2016), 2I-77; O. Peiffert, "Le recours d'un mouvement de libération nationale à l'encontre d'un acte d'approbation d'un accord international de l'Union: aspects contentieux (Obs. Ss l'arrêt Trib. UE Io déc. 2015, aff. T-512/12, Front Polisario c/ Conseil, RTD eur. 2016, I19, obs. C. Flaesch-Mougin)", RTD eur., (2016), 319-336; G. Poissonier, F. Dubuisson, "La question du Sahara occidental devant le Tribunal de l'Union 
has been written about this decision. The fact is - despite its controversial findings and outcomethat on this occasion the European Court - certainly the General - unexpectedly, dropped the well known "relative hermetisme de sa jurisprudence contemporaine à la norme conventionnelle"

In fact, such an attitude is crystal clear if we take into account the fact that on March 2014 a subsequent application was introduced by the Polisario Front against the Morocco-EU Fisheries Protocol of 2013, before the same Court and following the same arguments ${ }^{80}$. Then, it is understandable the panic of the Moroccan Government ${ }^{8 \mathrm{I}}$, that was accompanied by a strong pressure over European State Members - Spain obviously included. As a result, last March, Spain's Ambassador to Morocco, Mr. R. Díez-Hochleitner confirmed to the press that:

"Moroccan authorities were notified of Spain's decision to support the appeal made by the EU Council against the EU Court ruling of Io December 2015 concerning the agricultural agreement between the EU and the Kingdom of Morocco", ${ }^{82}$

The same move had been adopted on previous days by Spain's State Secretary of Foreign Affairs. According to Moroccan sources, during the sessions of the Human Rights Council in Geneva, Mr. I. Ybañez expressed the hope to see the Kingdom and the EU "move forward with a solution" ${ }^{\text {"3. }}$. Also, not surprisingly, in this line more than one hundred MEP members subscribed to a manifesto last April claiming for the preservation of the "higher strategic interests" of Morocco ${ }^{84}$, as a way of putting pressure on the undergoing process.

Finally, as expected, Spain is participating currently in the proceedings related to the appeal against the GC decision of Io December 20I5, helping the Council and the Commission ${ }^{85}$.

At the time of writing, the Opinion of the Advocate General has been publicized. Suffice it to say that, although clearly oriented to annul the previous ruling of the GC, among other reasons it is

européenne: une application approximative du droit international relatif aux territoires non autonomes", I43 JDI (2016), 503522; D. Simon, A. Rigaux, "Le Tribunal et le droit international des traités: un arrêt déconcertant", Europe (Actualité du Droit de l'Union Européenne), (2016-2), 5-II; J. Soroeta Liceras, "La sentencia de to de diciembre de 20Is del Tribunal General de la UE (T-5I2/I2), primer reconocimiento en vía judicial europea del estatuto del Sabara Occidental y de la subjetividad internacional del Frente Polisario", 38 RGDE (2016).

79 We take the expression from J.F. Delile, "L'invocabilité des accords internationaux devant le juge de la légalité des actes de l'Union Européenne. État des lieux à l'occasion des arrêts Vereninging Milieu defensieet Stichting Natuuren Milieu", 5I CDE (2015), I5I-I78, at 177, following M. Méndez, The Legal Effects of EU Agreements. Maximalist Treaty Enforcement and Judicial Avoidance Technique (Oxford UP, Oxford, 20I3).

8o The Application was introduced on 14 March 2014 against the Decision 2013/785/EU of the Council, of 16 December 20I3, related to the conclusion, on behalf of the European Union, of the Protocol between the European Union and Morocco on Fisheries (aff. T-180/I4). However, its admissibility by the GC seems doubtful insofar as delayed, according to the rules on deadlines governing the annulation remedy (Simon, Rigaux, supra n. 79, at 8 and footnote 26).

${ }_{8 \mathrm{r}}$ And even of his sympathizers. As a way of example, in the previously cited contribution of J.Y. De Cara, he attributes erroneously the Ruling of ro December 2015 to the Fisheries Protocol of 2013 (see "Souveraineté du Maroc...", supra n. 4 , at I3I): arrière pensée?

82 MAP Agency, Morocco-EU Agricultural Agreement; Madrid Notifies Rabat of its Decision to Support Appeal against EU Court Ruling, Release, Io March 2016 (accessed 25 June 2016).

83 Ibid.

${ }^{8}$ MAP, Press Release, April, 8th, 2016 (accessed 25 June 2016).

${ }_{8}$ In fact, on May 2016, Spain with some Member States (Belgium, Germany, France and Portugal) were granted leave to intervene in the dispute in support of the Council. However, Germany neither lodged a statement in intervention nor took part in the hearing, and Belgium, albeit participating, didn't made any oral submission. 
stated that the Polisario Front could not be considered as having legal interest (direct concern) in the proceedings insofar as Spain would currently remain the administering power of the territory ${ }^{86}$. However, such characterization is clearly in contradiction with the constantly reiterated official Spanish position, according to which:

"Spain has had no responsibilities in Western Sahara since 26 February 1976, when the Ambassador Representative of Spain to the United Nations addressed a letter to the Secretary General of the Organization affirming "Spain is considered hereinafter detached from any international responsibility in relation to the administration of that territory. This position is evoked repeatedly, year after year, in the annual statement to the UN General Assembly on autonomous territories. Spain is therefore not the administering power of Western Sahara, having renounced the effective exercise of that administration.

Since Spain has no effective control over the territory of Western Sahara, it is not in a position to exercise any functions and competences of the administering powers in accordance with the regime established in the UN Charter." ${ }^{\prime 7}$

In spite of this well known position, according to Advocate General Wathelet:

"It is true that since 26 February 1976 the Kingdom of Spain has considered itself exempt from any responsibility of any international nature in connection with the administration of Western Sahara. However, it cannot be categorically ruled out that, despite its withdrawal, the Kingdom of Spain has retained its status as administering power in international law and that, as such, it is the only entity to have the capacity, or indeed the obligation, to protect, including legally, the rights of the people of Western Sahara, in particular its right to self-determination and its sovereignty over the natural resources of the territory.

86 One of the main questions lies on the controversial legal personality of Polisario Front. Against the perception sustained by some authors (e.g. overtly Soroeta Liceras, "La Sentencia de Io de diciembre...", supra n. 79; more nuanced, Fleury Graff, supra n. 79, at 283-286, and Rodríguez Magdaleno, "La explotación de los recursos del Sahara...", supra n. 36, at 247), the GC failed to take it into account as an international subject (Ruling ro december 20I5, para. 46), opting for its characterization as private entity (para. 52), directly and individually concerned by the act of the Council (paras. III-II2). As has rightly pointed out: "the sui generis character of Polisario was not really taken into account, naturally the Court did not want to go into the uncomfortable discussion on NLM and tried to fit Polisario into another box. It did so by using case law that was not particularly relevant and it wasn't because the situation of a trade union or agence de voyage is simply not comparable" (M. Milanov, "Comment. II December 20I5" in "Trade Agreements, EU Law, and Occupied Territories (2): The General Court Judgment in Frente Polisario v Council and the Protection of Fundamental Rights Abroad”, EJIL: Talk! (accessed 20 May 20I6). On the same way, See Simon, Rigaux, supra n. 79, at 6). Certainly, the extent of the capacity of Polisario could be discussed in so far it is deprived of some characteristics of other NLMs according to the international practice (Gosalbo Bono, supra n. 79, at 36-40); however, in the light of the same practice, international capacity is undoubtedly greater than international rights attributed to opposition factions - not NLMs- worrying in the Syrian conflict, as inconclusively has been suggested (See Ph. Weckel, "Statut du Sahara occidental: les conclusions de l'avocat general devant la Cour européenne de justice”, 485 Sentinelle (17 September 2016) (accessed 20 September 2016), inasmuch as the Polisario Front is "constantly searching its diplomatic progression" (D. Burriez, "Chronique des faits internationaux", RGDIP (2016), at 403). In line with this, as has been observed, it would be more helpful and clear to recognize Polisario ius standi in terms of international legal personality (See Peiffert, supra n. 79, at 326-327).

87 Government response to the question submitted by the deputy Gaspar Llamazares Trigo (Political Group of The Plural Left) on the admission by the Government of the fact that Spain is still de jure administering power over the territory of Western Sahara, GCOJ (BOCG), no. 523, 25 September 20I4; in Actividades, Textos y Documentos..., 2014, at 710. Moreover, from a legal point of view, the inability of Spain's to resign its mandate as administering power - never recognized by United Nations - is examined in C. Ruiz Miguel, "Las obligaciones legales de España como potencia administradora del Sahara Occidental", 26 AEDI (2010), 303-331. 
Even though there is no need to settle this point in the present case, the wording of the obligation imposed on administering powers by Article 73(a) and (b) of the United Nations Charter gives me cause to doubt that they are able to release themselves from this role without having accomplished it having regard to the interests and needs of the people of the non-self-governing territory concerned.

This doubt is reinforced by the fact that the UN still considers that the obligation to transmit information on Western Sahara to the UN Secretary-General under Article 73(e) of the United Nations Charter applies to the Kingdom of Spain.

Furthermore, the Ministerio Fiscal (Office of the Public Prosecutor) of the Kingdom of Spain and the Audiencia Nacional (National High Court, Spain) recognise the status of the Kingdom of Spain as the administering power in Western Sahara, which 'as such, retains, until the end of the decolonisation period, the obligations under Articles 73 and 74 of the United Nations Charter, which include the protection, including judicial protection, of its citizens against any abuses'. On this basis, the Kingdom of Spain extended its international jurisdiction in criminal matters to crimes committed in Western Sahara." $" 8$

\section{(H) BY WAY OF CONCLUSION}

"Profound secrecy has some of the lustre of the divine. He who speaks lightly soon falls or fails."

Forty years has passed since the Spain's decision to relinquish its legal responsibilities over the Western Sahara. Its subsequent political attitude towards the territory -reflected in the official statement issued on 26 February 1976- confirmed, on the one hand, the inability of the Spanish Government to abide the international norms on self-determination; on the other hand, its failed attempts to remain outside the situation. The Spanish role, progressively self-conceived as a "constructive neutrality" has revealed a lot of contradictions, that has been solved through a patient but constant approach to the Moroccan thesis - expressed mainly in its passive role inside the Group of Friends of Western Sahara-, its muteness concerning the successive incidents related to the territory - specially concerning human rights situation-, its sympathies towards the Moroccan Autonomy Plan or its constant support - sometimes hidden, sometimes unveiled - to the measures related to the exploitation of Western Sahara natural resources due to the Spanish interests at stake.

Certainly, far from having a presumed role of a bridge to contribute to settle the conflict, the "constructive neutrality" - echoed by Spanish authorities and promoted by Spanish think-tanksappears really as a "benevolent neutrality” towards Morocco's position. A feeble, even pusillanimous, approach that proves the real limits of the Spanish foreign policy, and confirms the character as a State policy - shared by all political parties that have assumed Government responsibilities during these forty years - of the so-called "Spanish position" towards the Western Sahara issue.

88 Opinion, paras. I88-19I. As for the implications of Spain's judicial decisions, the Advocate General recalled that at the hearing Spanish Government "did not comment on the position of the Spanish judicial bodies and simply stated that it respected the decisions of the Spanish courts" (Ibid., para. 192).

89 B. Gracián, The Art of Worldly Wisdom [Oráculo Manual y Arte de Prudencia, 1647], (translated by J. Jacobs, I892), CLX. 
In spite of Spain's debilities, the picture portrayed proves at the same time, as has been accurately said, that:

"Nowadays, at the final steps of the Decolonization process, the principle of self-determination seems to have lost visibility, showing a weak institutional ability to extract from it the proper legal conclusions" 90

Certainly, the attitude of Security Council and the members of the international community -and specially the silent and evasive position of Spain - concerning Western Sahara issue is the best example.

90 A. Remiro Brotóns (ed.), Derecho internacional. Curso General (Tirant lo Blanch, Valencia, 20Io), at I2I (translation by the author). 